\title{
Study on Sponge City Planning in Central City of Tangshan
}

\author{
Luqi Wang ${ }^{1, \mathrm{a}}$, Guoqing $\mathrm{Li}^{2, \mathrm{~b}, *}$ and Xiaokang $\mathrm{Hu}^{3, \mathrm{c}}$ \\ ${ }^{1}$ Agricultural University of Hebei , HeBei 071000, China. \\ ${ }^{2}$ Agricultural University of Hebei , HeBei 071000, China. \\ ${ }^{3}$ China Architecture Desigh Group,Beijing100044,China.

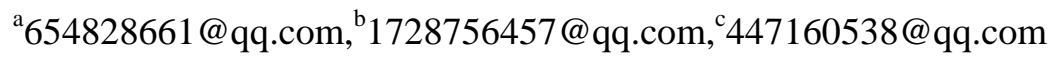

Keywords: Sponge City, City Center, Waterlogging.

\begin{abstract}
In order to study the impact of the Sponge City concept on the planning of existing urban centers, this article takes Tangshan central area as an example.Through the analysis of the geographical conditions, water resources, flood control and waterlogging capacity of the existing central city. The Sponge City low impact development concept is brought into the central city planning, which is hoped to have a certain guiding role in central city planning and construction.
\end{abstract}

\section{Introduction}

The acceleration of urbanization has promoted the progress of mankind. Making the contradiction between human development and natural ecology deepened. [1]In response to these circumstances, the concept of "sponge city" was first proposed in the 2012 Low-Carbon City And Regional Development Technology Forum in April 2012.Sponge city is the city can be like a sponge, in adapting to environmental changes and response to natural disasters have a good "flexibility". Sucking the water when it rains, and then storage the water. Finally, purify the water. When we need it,"Releaseing" the stored water and use it. To date there is still necessary to explore the research subject on how to implement the sponge city planning in the existing urban planning. Sponge city concept into the whole urban planning. Explore the city center city "to alleviate the water shortage, improve the water environment quality, remodeling water ecological quality, and strengthen water security" sponge city construction mode. Based on the relevant planning work of sponge city construction in Tangshan city center, this paper explores the planning of sponge city center area.

\section{The problem of Sponge City}

1)Experience in the relevant domestic construction is not sufficient, and imitate foreign research results seriously. The construction of "sponge city" in China is dominated by the government, they are carrying out urban ecological restoration and reconstruction. But some cities and regions facing that divorced from the present situation and outstanding problems at this stage. Their early related work is not perfect, concepts and techniques to master does not reach the designated position. It is not considered applicability that they rigidly apply the same construction model. There is still a gap between the renewal and development of sponge city concept.

2)The gray construction mode has a great influence on the central area. Some pilot cities are still unable to thoroughly implement the concept of sponge city construction. The original non-ecological projects were not terminated in time. The Urban roads and squares still follow the traditional pattern of construction. Heat island effect, urban waterlogging and other extreme phenomena occur frequently, and has not been contained. At the same time, At the same time, some projects did not respond to the call of sponge city construction, the gray construction mode on the ecological impact has continued. 
3)People are unfamiliar with the concept of sponge city, lack of awareness of the benefits brought by them, and most of them are not actively involved. This directly affects the development speed and construction quality of sponge city, the advanced urban construction technology cannot be popularized, and the traditional urban construction mode cannot be fundamentally changed.

\section{Case study of sponge city construction planning in central district of Tangshan city}

\subsection{Compiling background}

The construction of sponge construction in Tangshan city is in the exploration stage, and the city has passed the competitive review to become one of the first batch of 16 sponge cities in China.In Tangshan city based on the analysis of the status quo, combined with the goals of the "guidance", in general, the sponge of Tangshan downtown area planning and urban construction system layout, put forward the specific provisions of sponge of city construction, establish a perfect system of city sponge.

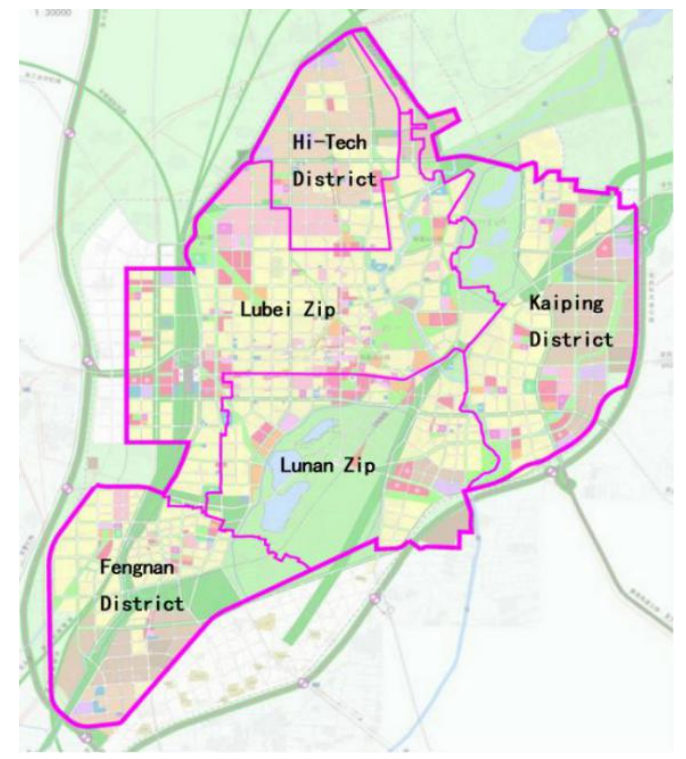

Fig. 1 Two or more references

\subsection{The status quo}

Tangshan is located in the central section of circum-Bohai Sea Gulf region, face the Bohai Sea in the south , depends on Yanshan mountain in the north, border Luanhe with Qinhuangdao city in the east,the west adjoin with Beijing, Tianjin. Tangshan City Center is divided into five parts, LuNan zip, LuBei zip, Hi-Tech District, Kaiping District, FengNan District. As show in Fig.1. East West high lying low. The general elevation is 14-32 meters and slope below 10 degrees.DaChengShan and FengHuang Park is that elevation higher in this area. The highest point is DaChengShan(Elevation 125.1 meters).

1)Natural rainfall is less

Tangshan belongs to warm temperate continental semi-humid monsoon climate type, hot and rainy in summer, cold and dry in winter.For several years, the average rainfall was $606.8 \mathrm{~mm}$,and evaporation is $800-1100 \mathrm{~mm}$. Among them, the rainy year rainfall more than 800 millimeters and a year with little rain only $300 \mathrm{~mm}$.

2)Water shortage in daily life

The per capita water resource in Tangshan city center is 231.3 cubic meters, which is only $67.64 \%$ of the city area. The total amount of water available in the central urban area is about 347 million cubic meters per year, or about $15.88 \%$ of the urban area. Moreover, And due to successive years of rainfall and groundwater serious overdraft, the three compound funnel areas of the urban, Tanghai-Ninghe, resulting in the urban area, Tanghai - Ninghe,Guye - Heiyanzi three large funnel area[2].Tangshan local water resource utilization ratio in accounted for nearly $80 \%$ of groundwater, 
surface water source of a single, low security of water supply security, the daily life in urban water relies heavily on DouHe reservoir DaHeiTing reservoir diversion, diversion ratio of more than 50\%.

3)Poor drainage and waterlogging capability

There are 37 internal waterlogging points in downtown Tangshan city, and the risk area of waterlogging is about 2 square kilometers. Downtown in most of the rainwater drain pipe top level is lower than the design flood level, and most of the regional network drainage design standard is less than 1 year once, can not meet the requirement of the new specification, there are serious security hidden danger.

4)Poor drainage and waterlogging capability

There are 37 internal waterlogging points in downtown Tangshan city, and the risk area of waterlogging is about 2 square kilometers.Downtown in most of the rainwater drain pipe top level is lower than the design flood level, and most of the regional network drainage design standard is less than 1 year once, can not meet the requirement of the new specification, there are serious security hidden danger.

\subsection{The construction goal and strategy of Tangshan sponge city}

According to the current Tangshan district planning layout, carefully study city location conditions, rainfall characteristics, geological and hydrological conditions, flood characteristics and water resources condition, the condition of water environment and water ecology and Tangshan economic development and people's life demand, flood control, drains and waterlogging risk assessment. The total control rate of annual runoff in Tangshan city was obtained, and the total control rate of annual runoff was $75 \%$, and the corresponding design rainfall was $24 \mathrm{~mm}$. As show in Fig. 1.For the current drainage area of Tangshan in Tangshan, the priority is to use the "delayed storage" method to reduce the total runoff volume and the peak runoff. And four categories are constructed, and 15 small index systems are designed to guide the overall construction of the sponge city and water system.As show in Table 1.

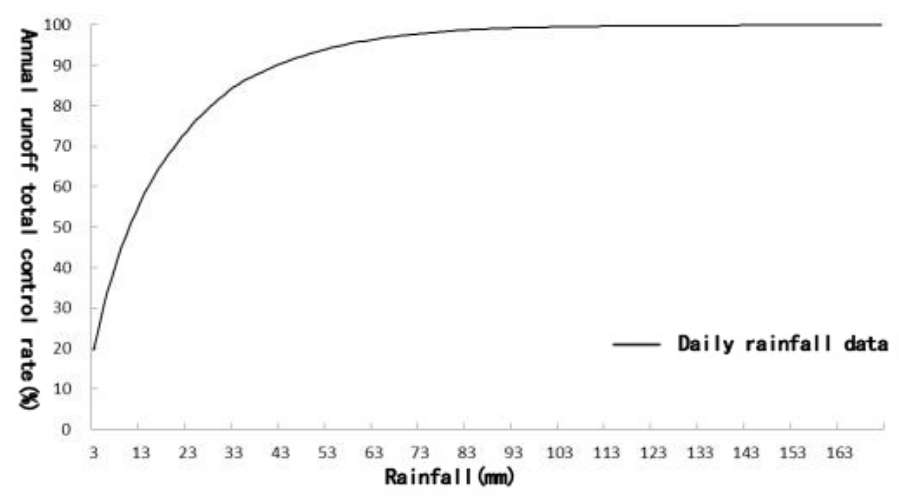

Fig. 2Daily rainfall data 
Table 1 Tangshan City Center Area Sponge City Goal.

\begin{tabular}{|c|c|c|c|c|}
\hline Category & Index & Unit & Status quo & 2030 target \\
\hline \multirow{6}{*}{ Water ecology } & $\begin{array}{l}\text { Annual runoff total } \\
\text { control rate }\end{array}$ & $\%$ & -- & 75 \\
\hline & $\begin{array}{c}\text { Standard } \\
\text { percentage of } \\
\text { sponge city area }\end{array}$ & $\%$ & -- & $\geq 80$ \\
\hline & $\begin{array}{l}\text { Shoreline rate of } \\
\text { ecological }\end{array}$ & $\%$ & 26 & $\geq 50$ \\
\hline & $\begin{array}{c}\text { Urban Heat-island } \\
\text { Effect }\end{array}$ & - & \multicolumn{2}{|c|}{ Heat island strength is mitigated } \\
\hline & Water surface ratio & $\%$ & 3.3 & no reducing \\
\hline & Groundwater level & $\%$ & -- & Basically stable \\
\hline \multirow{3}{*}{ Water safety } & $\begin{array}{l}\text { The Standard } \\
\text { waterlogging }\end{array}$ & - & -- & $\begin{array}{l}\text { The design of the } \\
\text { flooding system } \\
\text { has reached the } \\
\text { national standard }\end{array}$ \\
\hline & $\begin{array}{l}\text { Flood control } \\
\text { standards }\end{array}$ & - & - & $\begin{array}{c}\text { Meet the } \\
\text { requirements of } \\
\text { flood control } \\
\text { standards }\end{array}$ \\
\hline & $\begin{array}{l}\text { Drinking water } \\
\text { safety }\end{array}$ & $\%$ & 100 & 100 \\
\hline \multirow{3}{*}{$\begin{array}{c}\text { Water } \\
\text { environment }\end{array}$} & $\begin{array}{c}\text { Surface water } \\
\text { quality standards }\end{array}$ & - & $\begin{array}{l}\text { V and worse than } \\
\text { Grade V }\end{array}$ & Grade IV \\
\hline & $\begin{array}{l}\text { Groundwater } \\
\text { quality standards }\end{array}$ & - & - & $\begin{array}{l}\text { To meet the } \\
\text { functional } \\
\text { requirements of } \\
\text { groundwater }\end{array}$ \\
\hline & $\begin{array}{c}\text { Initial rainwater } \\
\text { runoff control rate }\end{array}$ & $\%$ & - & $\geq 45$ \\
\hline \multirow{3}{*}{ Water resource } & $\begin{array}{l}\text { Rainwater resource } \\
\text { replacement rate }\end{array}$ & $\%$ & - & $\geq 2$ \\
\hline & $\begin{array}{c}\text { Utilization of } \\
\text { sewage recycling }\end{array}$ & $\%$ & 37.5 & $\geq 60$ \\
\hline & $\begin{array}{l}\text { Pipe network } \\
\text { leakage control }\end{array}$ & $\%$ & 15.7 & $\leq 10$ \\
\hline
\end{tabular}

1)Water system planning and coordination

After research and analysis, It is found that the water resources, waterlogging, water security, water environment and water ecological problems are prominent in the planning area, and has had a serious impact on the production and life of local residents. Therefore, it is very important to solve the problems of water resources, water security, water environment and water ecology for the construction of the sponge city in planning area. To solve these four problems, there are four main requirements:(1) Open source widely, strengthen the perfection of the water allocation system, and ensure the ecological water demand of the city.(2) Strengthen capacity. Improve the construction of flood control and drainage system. Restoring LiGeZhuang's upstream occupied River; The Pomegranate River flood control standards from the current less than five years to upgrade to 50 years. Strengthen the construction of storm water mains for important drainage channels[3].(3) Water system governance. Develop a plan in river section about water ecological restoration. Re-shaping the city waterfront landscape. Natural country protection section: Maintain the natural form of the outer channel, create a ribbon wetland landscape; Ecological restoration demonstration section: Further strengthening the ecological service function of South Lake and its connected water 
bodies; Ecological landscape leisure section: Transformation of the surrounding ecological shoreline and the construction of waterfront greenway and hydrophilic space etc. As show in Fig. 3.

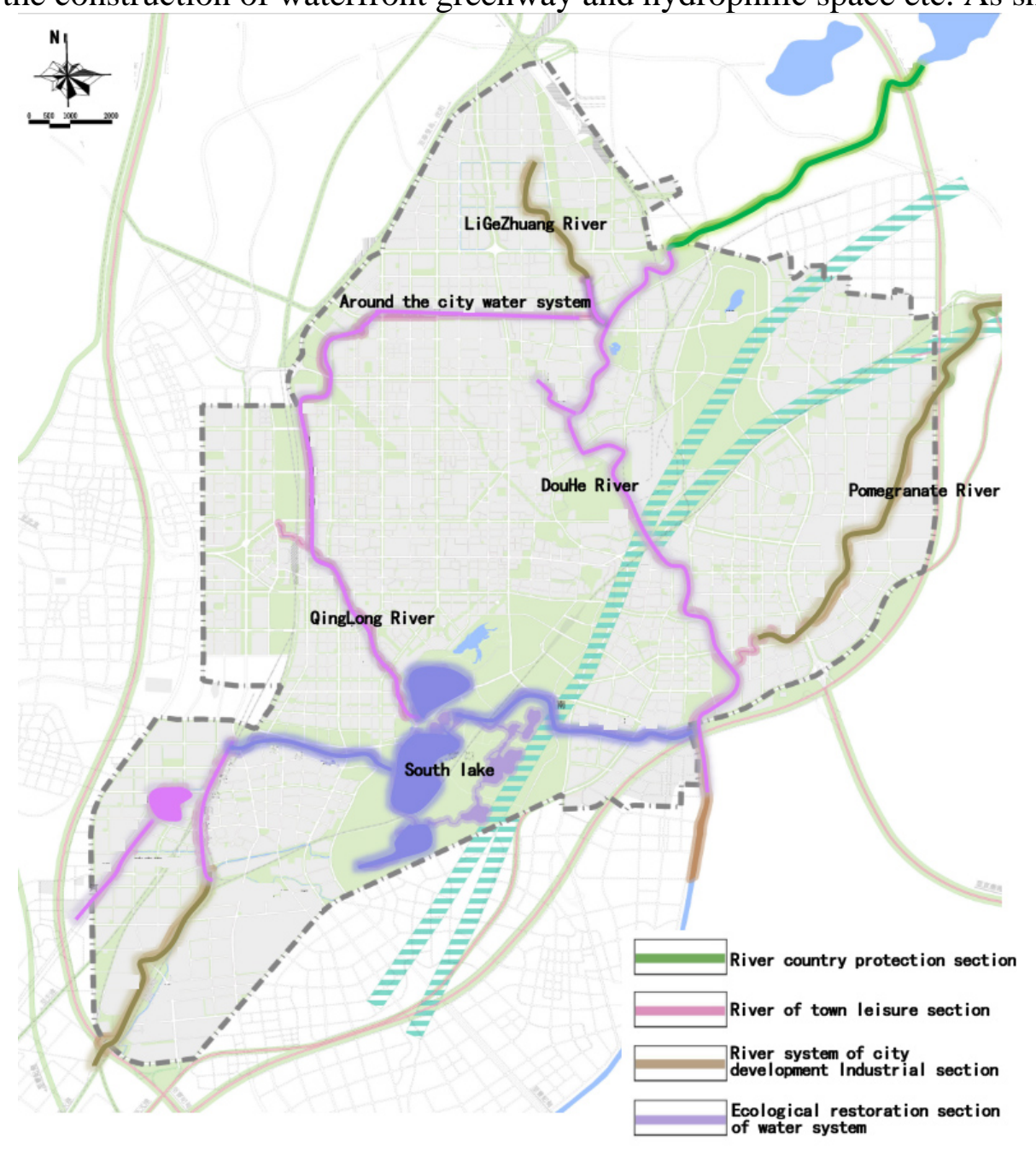

Fig. 3Guidelines for Ecological Restoration of Sponge Urban Water System 


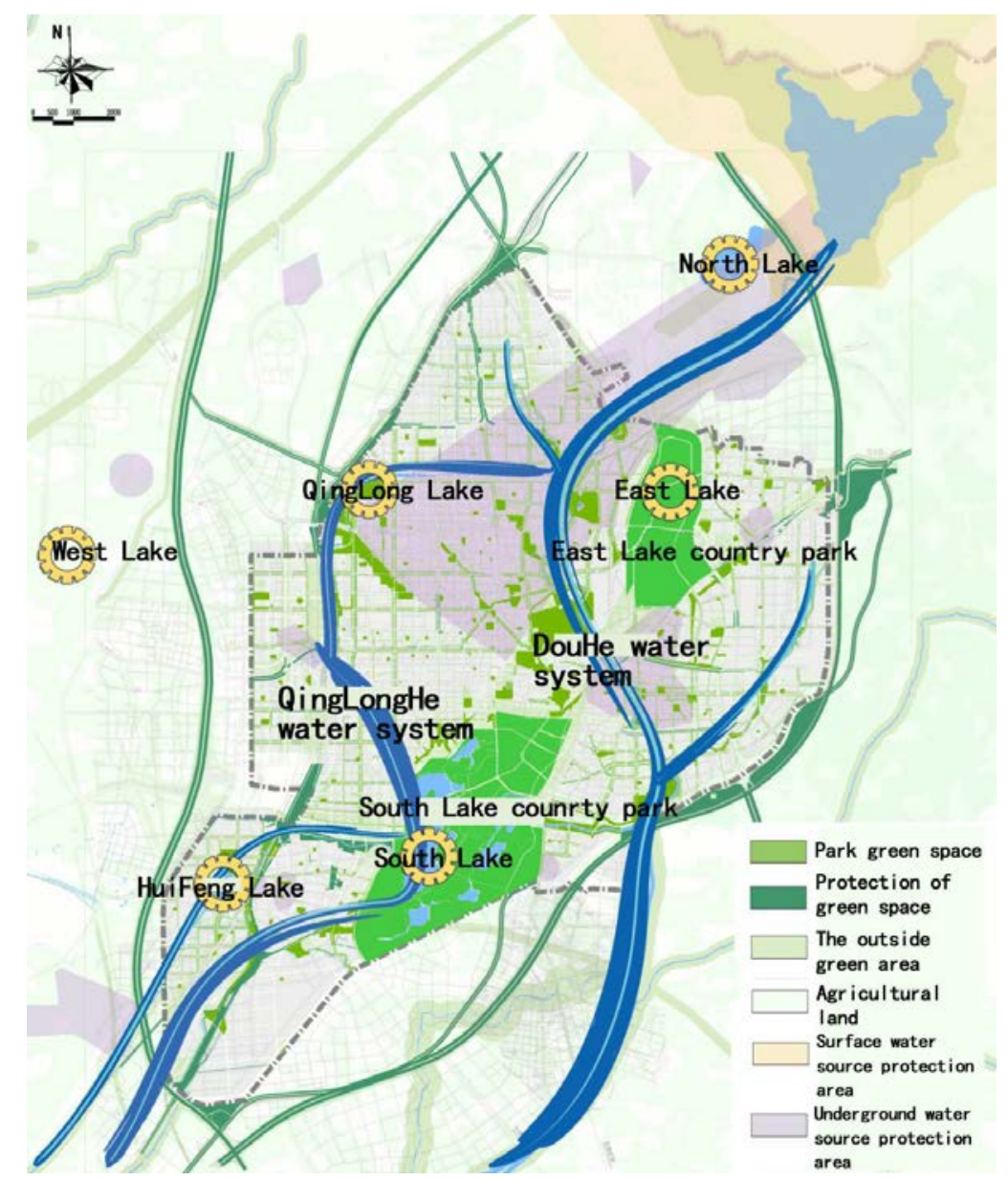

Fig. 4The ecological pattern of sponge city in Tangshan central city

2) The construction of ecological pattern of Sponge City

Based on ecological background condition of Tangshan city center, overlay analysis of the status quo of ecological factors, combing the current situation of the central area of ecological security pattern, with the regional ecological space pattern, conservation center in the city[4]."River, fields, lakes, sea, forest, wetlands "and other natural ecological background, build the center city to build, "Two country parks and many parks. Two rivers and six lakes "of the ecological security pattern." Two country parks" refers to the South Lake Country Park and East Lake Country Park. Parks for DaChengShan and FengHuang Park and other 45 parks. "Two rivers" means DouHe and its tributaries (ShiLiu River, etc.), QingLongHe water system (Round-The-City Water, etc.) and its connections. "Six Lake" is the South Lake, East Lake, QingLongHu Lake, HuiFeng Lake, West Lake North Lake and other etc. 6 sponge wetland parks. As show in Fig. 4.Finally, a smooth and safe sponge pattern can be constructed by the main functions and sponge acuity of the spongy body in different regions, so that the integrated effect of the spongy body can be fully played. To strengthen the function of the east lake and South Lake in the central area. To ensure the drainage capacity of urban watercourses such as the steep river with the main discharge. The relationship between "grey" and "green" is balanced by emphasizing the road and the green space in the street. The use of land in the square to meet its own water needs.

3)Control of urban construction of sponge city

In order to implement the ecological pattern protection and ecological restoration requirements of the Beijing-tianjin-hebei region. The sponge pattern is the skeleton, and the blue and green line control is the means to implement the public sponge space[5]. The control rate of runoff volume is controlled by no less than $65 \%$.If no construction or modification is carried out, the status quo is not required. The total control rate of runoff volume control is about $80 \%$ in the area with better construction conditions such as South Lake, High-Tech Zone, FengNan west region and KaiPing district. 


\section{Conclusion}

The construction of sponge city is still at an early stage in China, and the planning methods, construction approaches and management guarantee measures should be explored. From the source of urban planning, it can effectively alleviate water environment problems such as urban waterlogging, runoff pollution and water shortage. Coordinate the planning of each level, so that the architecture, landscape, drainage, water conservancy and other majors can be effectively connected. The construction of sponge city must strengthen the emphasis on urban characteristics and the strategic measures of local conditions, strengthen the implementation of the management, strengthen the determination of the mandatory index and the connection and implementation of the statutory plan.

\section{References}

[1]HongTao Ma,Dan Zhou,CaiXia Kang,JiangLei Wang,The idea of compiling the special planning of sponge city and practice in Zhuhai,Planners,2016,(05):29-34.

[2]XueQing $\mathrm{Xu}$,Reform the current distribution system and establish a scientific and effective water right system,Haihe Water Resources,2001,(02):1-2

[3]Tong Wang,Study on urban rainwater logging in China from the perspective of urban planning,Huazhong University of Science \& Technology,2013.

[4] Ministry of Housing and Urban-Rural Development,Interim Provisions on the preparation of special plans for sponge cities.

[5]HongLiang Lv,DeMiao Yu,Lin Xiong,Discussion on technical ideas and key points of preparation of special planning for sponge City-Taking the special planning of sponge city construction in Tianjin as an example,Construction technology,2016,(15):20-23+27. 